\title{
Belgian regional parliaments and the European Union: an analysis of parliamentary scrutiny in agricultural and environmental policies
}

\section{François Randour \& Wouter Wolfs}

To cite this article: François Randour \& Wouter Wolfs (2017): Belgian regional parliaments and the European Union: an analysis of parliamentary scrutiny in agricultural and environmental policies, The Journal of Legislative Studies, DOI: 10.1080/13572334.2017.1329988

To link to this article: http://dx.doi.org/10.1080/13572334.2017.1329988

Published online: 01 Jun 2017.

Submit your article to this journal

Џ Article views: 1

Q View related articles $\sqsubset$

View Crossmark data $\nearrow$

Citing articles: 1 View citing articles $\widetilde{ }$ 


\title{
Belgian regional parliaments and the European Union: an analysis of parliamentary scrutiny in agricultural and environmental policies
}

\author{
François Randour ${ }^{\mathrm{a}}$ and Wouter Wolfs ${ }^{\mathrm{b}}$ \\ anstitut de Sciences Politiques Louvain Europe (ISPOLE), Université catholique de Louvain,

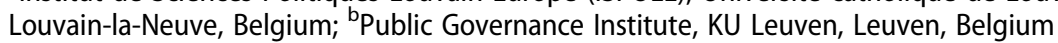

\begin{abstract}
Drawing on qualitative case studies of two specific European decision-making processes in the agricultural and environmental sectors, this paper discusses how and why Belgian regional parliaments activated (or not) their control mechanisms to scrutinise their respective regional ministers. The findings show that parliamentary scrutiny of the agricultural and environmental policy fields has undergone a process of institutional and behavioural Europeanisation. Belgian regional parliaments rely mostly on classical parliamentary tools aimed at gathering information and, to a lesser extent, on constraining instruments aimed at influencing their government. Rather than trying to influence the EU negotiations, the MPs try to assess the potential impact of the reforms on their regional policy sectors. The findings also demonstrate that domestic media coverage and political salience of the EU negotiation associated with important implementing powers of regional parliaments have a positive effect on the level of scrutiny conducted by Belgian regional assemblies.
\end{abstract}

KEYWORDS Subnational parliaments; regional parliaments; European integration; agricultural policy; environmental policy; Common Agricultural Policy

\section{Introduction}

With the introduction of the early warning system (EWS), the Treaty of Lisbon opens the door for the inclusion of subnational parliaments in the EU decision-making processes. In its Protocol 2, subnational parliaments with legislative powers are recognised as such: 'it will be for each national Parliament or each chamber of a national parliament to consult, where appropriate, regional parliaments with legislative powers'. On this matter, Belgium added a Declaration to the treaty stating that its regional parliaments are on an equal footing with the national parliament with regard to EU affairs.

So far, two types of study can be found in the literature on subnational parliaments. First, several comparative studies analyse the role of subnational parliaments with legislative powers (Abels \& Eppler, 2016), some with a 
special focus on the application of the EWS (Borońska-Hryniewiecka, 2013a, 2013b; Schmitt, Ruys, \& Marx, 2013; Vara Arribas \& Bourdin, 2011). Second, next to these comparative studies, individual case studies of the German (Schneider, Rittberger, \& Wonka, 2014), the Spanish (Carmona Contreras, 2012), the Scottish (Carter \& McLeod, 2005) and the Belgian (Bursens, Maes, \& Vileyn, 2015) subnational parliaments have also been conducted. These studies are relevant as they map the institutional developments regarding European affairs at the subnational level, allowing an assessment of the degree of institutional Europeanisation of Belgian subnational parliaments (Goetz \& Meyer-Sahling, 2008). Yet, little is known so far on the behavioural Europeanisation of regional parliamentarians. Indeed, to go beyond the developments of formal institutions, one has to look at the actual behaviour and strategies of parliamentary actors (Goetz \& Meyer-Sahling, 2008). On this matter, less attention is given to in-depth analysis of the scrutiny conducted by subnational parliaments in specific policy fields or on specific EU negotiations. Looking at parliamentary scrutiny at the policy field level is innovative as it offers a more detailed picture of the Europeanisation process taking place in (sub)national parliaments. This contribution fills that gap by examining the parliamentary scrutiny of Belgian subnational parliaments in the policy fields of agriculture and environment in the 2009-14 legislative period. More specifically, we focus on the 2013 reform of the Common Agricultural Policy (CAP) and on the negotiation of the EU's financial instrument for environmental, nature conservation and climate action projects throughout the EU, commonly known as 'LIFE'.

Bursens and Högenaueur (2017, this issue) highlighted three ways of participation for subnational parliaments in the EU policy-making process. The first one focuses on the ways to influence the policy-making activities at the European level (EWS and Committee of the Regions) while the second type focuses on the domestic level: controlling the position of the executives. The third way of participation for subnational parliaments lies in the multilevel environment in which they operate: subnational parliaments can indeed network with other legislative or executive actors (both vertically and horizontally). This article focuses on the second type of participation of subnational parliaments in the EU policy-making processes: controlling the executive. Taking a case-specific approach, the objective of this paper is twofold: understanding how Belgian subnational parliaments scrutinise their executive and why they activated (or not) the control mechanisms at their disposal to scrutinise their regional ministers. Indeed, despite similarities in the negotiation process and in the CAP and LIFE policies (see below), a significant variation is observed in the level of parliamentary scrutiny. While the 2013 CAP reform was actively scrutinised by both Belgian subnational parliaments, the LIFE negotiation received only limited attention of parliamentarians. 
The next section proposes a state of the art on the adaptation of Belgian subnational parliaments to the EU integration and presents the analytical framework of this research. The third section discusses the case selection and measures the parliamentary scrutiny conducted by Belgian subnational parliaments on the CAP and LIFE reforms. In the fourth section, we address the second objective of this contribution: understanding the reasons behind the variation in the parliamentary scrutiny on the CAP and LIFE policies. The article ends with a discussion of the limits of the research and a summary of the results.

\section{Belgian subnational parliaments and European affairs}

Relying on the work conducted by Auel, Rozenberg, and Tacea (2015b) on the OPAL project, we first give an overview of the institutional strength of the Flemish and Walloon parliaments (hereafter 'Belgian subnational parliaments') by looking at the scrutiny infrastructures, their access to information and their formal capacity to constrain the government. Second, the section discusses the measurement of our dependent variable (parliamentary activities of Belgian subnational parliaments) and ends with the identification of independent variables explaining why Belgian subnational parliaments use their control mechanisms to scrutinise EU proposals.

\section{What we know on parliamentary scrutiny of European affairs in Belgian subnational parliaments}

Coming back to the institutional strength of Belgian subnational parliaments in EU affairs, the scrutiny infrastructure of both parliaments went through several transformations. First, the Walloon parliament created a committee dealing specifically with EU affairs and the Flemish parliament decided to merge EU with international affairs in a common committee (European Affairs Committee). Second, sectoral EU issues are mostly decentralised to the standing committees, which take the lead in the scrutiny process. Third, both parliaments have developed administrative units to handle EU documents (Schmitt et al., 2013). Nonetheless, the overall number of administrators working on EU affairs stays relatively low.

In terms of informational capacities, following the introduction of the EWS, Belgian subnational parliaments can now access legislative proposals coming from the EU. Yet, neither the Flemish nor the Walloon parliaments has direct access to EU negotiation limité documents, nor do they receive governmental memorandums on a regular basis (Interview 4). Another source of information could be found in the (de)briefings of ministers after meetings of the Council of the EU, but in both parliaments the presence of the minister is irregular and varies greatly between committees (Bursens et al., 2015). When 
looking at the constraining instruments available to Belgian subnational parliaments, the overall power of Belgian subnational parliaments is limited, as Belgian subnational parliaments do not have a mandating or a scrutiny reserve mechanism. This situation can be explained by Belgian institutional characteristics. The decentralisation of competences to the regional level combined with a high level of party discipline in all legislatures (De Winter \& Wolfs, 2017; Depauw, 2003) has increased the interdependencies between the different governmental levels. As a consequence, Belgian political parties are 'in the driver's seat of Belgian Politics' (Delreux \& Randour, 2015, p. 154), which renders the use of constraining instruments more difficult. Knowing this, and in line with Auel et al. (2015b), we consider parliamentary resolutions as a scrutiny instrument with a strong policyinfluencing function vis-à-vis the government. In Belgium, resolutions are indeed the result of an intense internal coordination process among the majority parties and are used as a strong political signalling tool towards the government.

\section{Measuring and explaining parliamentary scrutiny of subnational parliaments in Belgium}

In terms of our dependent variable, we focus on the variation in the scrutiny activities conducted by Belgian subnational parliaments on two specific EU negotiations: the 2013 CAP reform and the 2013 LIFE reform. As rightly noted by Auel (2007), formal powers given to parliaments do not always mean that they will be used in practice. We thus aim at measuring the activated control mechanisms used by Belgian subnational parliaments in a case-specific way.

Following Winzen's (2013) categorisation of parliamentary oversight institutions, we look at two types of parliamentary activity. The first type consists of actions tackling informational asymmetries between the government and their parliament. In this respect, several parliamentary instruments can be used to gather information on EU decision-making processes. The parliament can organise (de)briefings of Council of the EU meetings or parliamentarians can use interpellations but also oral, written, and topical questions. On this matter, in line with Rozenberg and Martin (2011; see also Martin, 2011), we consider that the analysis of parliamentary questions is an interesting method to learn information on the preferences and behaviour of parliamentarians. The second type of instruments addresses 'parliamentary authority losses' (Winzen, 2013, p. 300), namely the use by parliaments of a mandating system (see Auel, Rozenberg, Thomas, \& Tacea, 2012) and of parliamentary resolutions.

In this contribution, EU scrutiny actions of Belgian subnational parliaments were coded as follows. First, for the legislative term 2009-14, all 
parliamentary actions tackling environmental and agricultural issues were listed using the respective databases of the Flemish and Walloon parliaments (4238 parliamentary actions in total ${ }^{1}$ ). Second, we identified EU-related activities by coding each scrutiny action manually. This step allowed mapping the overall EU activity of Belgian subnational parliaments on agricultural and environmental issues at the policy field level. A parliamentary action was coded 'European' if it mentioned explicitly EU directives, regulations or EU institutions. Parliamentary actions referring to the EU for benchmarking or contextualisation purposes only were not considered as 'European'. Subsequently, we zoomed on our two case studies by counting all parliamentary actions mobilised by the Flemish and Walloon parliaments to scrutinise their government on the CAP and LIFE reforms.

In line with the second objective - why the subnational parliaments engage in this scrutiny behaviour - the rest of the section identifies explanatory factors affecting the level of activity of Belgian subnational parliaments. What we learn from recent literature on national parliaments is that variations in the level of parliamentary activity on EU affairs are best explained by a mix of institutional capacities and motivational incentives (Auel \& Christiansen, 2015; Auel, Rozenberg, \& Tacea, 2015a). Gattermann and Hefftler (2015) argue that 'beyond institutional capacity, the political motivation of national parliaments is a crucial determiner of their involvement in the EWS' (p. 307). The authors highlight that MPs, acting as rational actors, must decide on how to invest their limited resources. Motivations to do so can be found in career or electoral goals - depending among others on public opinion attitudes and salience of the EU proposal - or on policy influence goals. Taking this into consideration and in light of available data, two explanatory factors were selected in this article.

One factor often associated with the need of political incentives is the mediatisation of EU issues. On this matter, De Wilde (2008) demonstrated in a case study of the Netherlands that 'Limited media coverage of EU policy-formulation processes reinforces executive dominance whereas more intensive media coverage starts providing a weapon of the weak and increases the involvement of national parliaments' (p. 14). De Ruiter's (2013) analysis of Dutch and British MPs points in the same direction. In brief, the author argues that when a directive receives media attention, MPs will more easily invest resources to scrutinise the EU proposal, as it can be seen as an opportunity for electoral gains. Based on the following, a relation can thus be established between the level of domestic media attention and the level of activities of parliaments.

H1: The higher the level of media coverage of EU issues at the domestic level, the higher the level of parliamentary activity.

Using GoPress Academics, four written newspapers were screened to identify articles that had as their main focus the LIFE programme or the CAP: Le Soir 
and La Libre Belgique for French-speaking newspapers and De Morgen and De Standaard for Dutch-speaking newspapers. In addition, parliamentary actions conducted by MPs on the CAP and LIFE were analysed to check whether parliamentarians make direct references to media or specialised publications in their questions.

The second explanatory factor we address in this article is the political salience of the EU negotiation. Saalfeld (2005) explains that

Parliaments are likely to create institutional capabilities to monitor and influence national government policy at the EU level if the political saliency of EU affairs and/or the issue (defined as electoral saliency and the importance given to the issue at elite level) is high. (Saalfeld, 2005, p. 358)

Finke and Dannwolf (2013) but also Gattermann and Hefftler (2015) investigated the impact of issue salience on parliamentary scrutiny and found a positive effect on parliamentary activity.

Political salience is understood in this contribution as the importance given by the Council of the EU to a certain issue. The rationale is the following: MPs are expected to exert more control on their government for EU issues that are more frequently and thoroughly debated at the EU level (De Ruiter, 2013). Yet, saliency of EU negotiations is not sufficient to trigger parliamentary controls, as De Ruiter finds only moderate support for his hypothesis. Taking this one step further, in federal countries, to understand the activation of parliamentary control in case an EU negotiation is politically salient, the overall division of competences between the domestic political levels and, more particularly, the potential influence of parliaments in the implementation stage (policy-seeking goal) must be considered. Indeed, if a salient EU negotiation does not primarily concern a policy field on which parliaments can exert influence during the implementation, parliamentary control activities are expected to stay relatively low. Based on the following, we thus hypothesise that:

H2: The higher the salience of an EU negotiation and the parliament's role in implementations processes, the higher the level of parliamentary activity.

To operationalise salience at the EU legislative proposal, we follow De Ruiter (2013) by looking at 'A' (minor issues) and 'B' points at the agendas of Council's meetings. Nevertheless, as noticed by Gattermann and Hefftler (2015) citing Warntjen (2012), procedural aspects of EU decision-making processes should rather be considered as a 'consequence of salience', rather than salience as such. Taking this argument into account, we discuss the salience of the EU negotiation and the implementing role of parliaments in a qualitative way, relying on desk research and semi-structured interviews. 


\section{Parliamentary scrutiny of the CAP and LIFE reforms in the Flemish and Walloon parliaments}

The choices of Belgium and of the agricultural and environmental policies are interesting for the following reasons. Regarding Belgium, one of the key characteristics of its political system is its multi-level nature embedded in a type of legislative federalism, where there is no hierarchy of norms between the federal and the regional levels. Hence, acts adopted by Belgian (sub)national parliaments or their respective governments stand on equal footing with each other. In addition, the regional levels are responsible for conducting foreign policy for their competences - the 'in foro interno, in foro externo' principle (Beyers \& Bursens, 2006). In practice, this is illustrated by the way Belgium is represented in the Council of the EU. In the environment configuration of the Council, it is a regional minister (assisted by the federal level) that represents Belgium, whereas in the agricultural configuration of the Council, the federal government represents Belgium. The latter acts as 'a spokesman for the regions' (Beyers, Delreux, \& Steensels, 2004, p. 126) and the definition of the national position lies at the regional level (Interview 5). Consequently, the agricultural and environmental sectors are key policy areas in which the subnational level is pivotal.

Regarding the case selection, we argue that the CAP and the LIFE reforms are sufficiently similar to compare. First, both EU legislative proposals were negotiated during the years 2011-13 and resulted in the adoption of European regulations. These two negotiations took place in parallel (one in the agriculture configuration of the Council, the other in the environment configuration of the Council), which allows discussing and comparing potential parliamentary scrutiny before, during and after the EU negotiations, as this contribution covers the 2009-14 legislative period. Second, the negotiations of the LIFE and of the CAP reforms are both a revision of an existing policy. Indeed, the CAP is one of the oldest EU competences (Nugent, 2006). As regarding LIFE, the first programme was adopted in 1992 with the implementation of the 'LIFE 1' programme (1992-95), which was subsequently renewed with LIFE II, LIFE III and LIFE+. Finally, both the CAP and LIFE have a redistributive dimension (respectively for farmers and for environmental projects) and their negotiations were thus dependent on the adoption of the EU multiannual financial framework, which was mainly negotiated in the general affairs configuration of the Council where Belgium is represented by the federal level (Diplomatie Belgium, 2016).

\section{A significant variation in the parliamentary scrutiny of the CAP and LIFE reforms}

We first discuss the EU activity of the subnational parliaments in the agricultural and environmental policy fields. Looking at the EU-related share of 
parliamentary actions can indeed provide an overview of their behavioural Europeanisation. On this matter, empirical data show that EU-related questions in both sectors are numerous, with only minor differences between the Flemish and Walloon parliaments (see Tables 1 and 2). First, agriculture attracts the most EU attention, with an average of 28-29 per cent of EU actions in Belgian subnational parliaments. Environmental issues were, to a lesser extent, scrutinised, with an average of 13-15 per cent of EU-related actions in both parliaments. Second, when looking at the scrutiny activities at the level of MPs, only a minority of MPs has a high number of scrutiny activities, and among this group only a small number of MPs are responsible for a great share of EU-related activities. Yet, scrutiny actions in the field of agriculture are more concentrated among a limited number of MPs compared with environment. ${ }^{2}$ In addition, no clear pattern is observed in the type of instruments used by MPs, as they rely and activate the full range of control mechanisms at their disposal.

Focusing now on our CAP and LIFE case studies, the scrutiny behaviour of the Flemish and Walloon parliaments is again similar: the level of activities in

Table 1. EU and non-EU activity in agricultural and environmental policies - Flemish parliament.

\begin{tabular}{|c|c|c|c|c|c|c|}
\hline \multicolumn{7}{|c|}{ Flemish parliament } \\
\hline $\begin{array}{l}\text { Informational } \\
\text { focus }\end{array}$ & $\begin{array}{l}\text { Total actions } \\
\text { in agriculture }\end{array}$ & $\begin{array}{l}\text { EU-related } \\
\text { actions }\end{array}$ & $\begin{array}{l}\text { CAP } \\
\text { reform }\end{array}$ & $\begin{array}{c}\text { Total actions in } \\
\text { environment }\end{array}$ & $\begin{array}{l}\text { EU-related } \\
\text { actions }\end{array}$ & $\begin{array}{l}\text { LIFE } \\
\text { reform }\end{array}$ \\
\hline $\begin{array}{l}\text { Written } \\
\text { questions }\end{array}$ & 514 & 111 (21.9\%) & 27 & 766 & 65 (8.5\%) & 0 \\
\hline Oral questions & 253 & 110 (43.5\%) & 30 & 103 & $42(40.8 \%)$ & 0 \\
\hline $\begin{array}{l}\text { Topical } \\
\text { questions }\end{array}$ & 60 & 19 (31.7\%) & 6 & 19 & 7 (36.8\%) & 0 \\
\hline Interpellations & 6 & $3(50 \%)$ & 1 & 19 & 6 (31.6\%) & 0 \\
\hline Total & 833 & $243(29.2 \%)$ & 64 & 907 & 120 (13.2\%) & 0 \\
\hline \multicolumn{7}{|c|}{ Constraining focus } \\
\hline Resolutions & 4 & 1 & 1 & 19 & 5 & 0 \\
\hline
\end{tabular}

Table 2. EU and non-EU activity in agricultural and environmental policies - Walloon parliament.

\begin{tabular}{|c|c|c|c|c|c|c|}
\hline \multicolumn{7}{|c|}{ Walloon parliament } \\
\hline $\begin{array}{l}\text { Informational } \\
\text { focus }\end{array}$ & $\begin{array}{l}\text { Total actions } \\
\text { in agriculture }\end{array}$ & $\begin{array}{l}\text { EU-related } \\
\text { actions }\end{array}$ & $\begin{array}{l}\text { CAP } \\
\text { reform }\end{array}$ & $\begin{array}{c}\text { Total actions in } \\
\text { environment }\end{array}$ & $\begin{array}{l}\text { EU-related } \\
\text { actions }\end{array}$ & $\begin{array}{l}\text { LIFE } \\
\text { reform }\end{array}$ \\
\hline $\begin{array}{l}\text { Written } \\
\text { questions }\end{array}$ & 594 & $153(26 \%)$ & 34 & 1193 & $196(16.4 \%)$ & 5 \\
\hline Oral questions & 251 & 75 (30\%) & 27 & 529 & 93 (16.6\%) & 0 \\
\hline $\begin{array}{l}\text { Topical } \\
\text { questions }\end{array}$ & 33 & $16(48.4 \%)$ & 6 & 60 & $10(16.4 \%)$ & 0 \\
\hline Interpellations & 12 & $9(75 \%)$ & 4 & 22 & $4(18 \%)$ & 0 \\
\hline Total & 890 & $253(28 \%)$ & 71 & 1577 & $243(15 \%)$ & 5 \\
\hline \multicolumn{7}{|c|}{ Constraining focus } \\
\hline Resolutions & 3 & 2 & 1 & 5 & 2 & 0 \\
\hline
\end{tabular}


both assemblies was higher for the CAP reform than for the LIFE reform. During the years 2009-14, 128 scrutiny actions with the CAP as their main issue were identified, and only five in total for the LIFE policy. Tables 1 and 2 summarise the overall activity of the Flemish and Walloon parliaments in the agricultural and environmental policy field, present the share of EUrelated actions in these policy fields and outline the number of parliamentary actions on the specific cases of the CAP and LIFE reforms.

When looking at the informational focus of parliamentary activities, most of the discussions on the CAP reform were conducted in the agricultural committees of both parliaments, and only to a lesser extent in the plenaries. Conversely, the LIFE programme was never discussed directly in the parliaments: the only scrutiny actions found are written questions in the Walloon parliaments. Written questions are the most indirect form of parliamentary control: both the minister and quite often the MPs delegate this task to their administrations and assistants (Rozenberg \& Martin, 2011).

The parliamentary tools that were activated regarding the CAP reform took various forms - MPs used interpellations, topical, written and oral questions - and were used before, during and after the negotiations at the EU level. Yet, a difference exists between the Flemish and Walloon parliaments on the structural monitoring of the government on the CAP reform. In the Flemish parliament, members of the Agriculture Committee were briefed every three months on the results of the past Council meetings, either by the Flemish minister of agriculture or by the Flemish agricultural attaché of the Permanent Representation. Hence, Flemish MPs could rely on systematic governmental information, despite the fact that the debriefings were generally very limited in time (Interviews 8, 9, 11). In the Walloon parliament, no such debriefings were organised during the negotiations and parliamentarians had to get the information themselves (Interviews 2, 3). Still, two ex post debriefings were organised by the Walloon minister to present the content of the CAP reform (the first and second pillars) and to discuss its implementation. Yet, in both parliaments, not all political groups and MPs were equally active on the CAP issue. Only MPs who were part of the Agriculture Committee were active. The interviewees of both parliaments confirmed that interest in CAP reform outside the Agriculture Committee was rather limited (Interviews 1, 3).

As regards the timing of the parliamentary scrutiny, the majority of actions took place during the negotiations, hence when the informational asymmetry between the minister and his parliament is higher. Indeed, the two-level game nature (Putnam, 1988) of Council decision-making - a three-level game in the case of federal member states - makes access to information more difficult for parliamentarians as deliberations in the Council of the EU, and especially during trialogues, is less transparent. In addition, parliamentary scrutiny conducted after a deal on the CAP was reached at the EU level is also significant. 
Now focusing on the constraining focus of oversight institutions, no resolutions were adopted regarding the reform of the LIFE programme. Conversely, both the Flemish and the Walloon parliaments adopted a resolution on the upcoming CAP reform. This situation is noteworthy, especially knowing that resolutions in Belgium are rarely used. In the process of adopting their opinions, both parliaments organised several hearings with key stakeholders. The Flemish parliament adopted its resolution, backed up by a large majority, on 24 November 2010. The Walloon parliament adopted its resolution with unanimity in June 2011. Both resolutions are short documents of two to four pages giving general guidelines, which is partly explained by the fact the resolutions were not aimed at defining a precise mandate of negotiations for their governments. Finally, both parliaments stated their position before the European Commission officially launched its legislative proposals on the new CAP in October 2011.

To sum up, this section has shown that both agricultural and environmental policy fields have undergone a process of Europeanisation. The biggest share of EU questions is found for agricultural policies, but EU questions are also regularly discussed in relation to environmental policies. On the specific cases of the LIFE and CAP reforms, two contrasting situations are observed. On the one hand, the negotiations of the new LIFE programme triggered only limited parliamentary activity. On the other hand, a lot of parliamentary activities are observed on the CAP reform, with both parliaments using their full range of informational and constraining parliamentary instruments. The next section focuses on why the Walloon and the Flemish parliaments showed different scrutiny behaviour for the CAP and LIFE reforms.

\section{Explaining the activity of the Walloon and Flemish parliaments on the CAP and LIFE reforms}

We now turn to discussing our findings. The first factor analysed is the degree of media coverage. Our data show that there is clearly more mediatisation of the CAP reform than of the LIFE reform. No systematic attention is given to the LIFE programme in the media, with only a few short articles on specific projects that were funded by the programme. Hence, in addition to their limited quantity, the media coverage of LIFE in Belgian newspapers did not deal directly with the negotiations of the new LIFE programme. Conversely, the CAP reform benefited from extensive media coverage, with numerous articles covering the reform of the CAP, the positions of the key players at the EU level, but also more specific topics closely linked to the EU negotiations: the budget given to CAP policies, the allocation of subsidies to farmers (known as direct payments) and the greening of the CAP. Table 3 provides an overview of the media coverage of the CAP and LIFE reforms in the period 2009-14. 
Table 3. References in the French- and Dutch-speaking newspapers on the CAP and LIFE reforms.

\begin{tabular}{lcc}
\hline & CAP reform & LIFE reform \\
\hline French-speaking newspapers & 186 & 23 \\
Dutch-speaking newspapers & 43 & 6 \\
\hline
\end{tabular}

In brief, we thus observe a high level of media coverage for the CAP reform, an issue thoroughly debated in Belgian subnational parliaments, and a low level of media coverage in the case of the LIFE programme, a topic that saw limited parliamentary scrutiny. Taking this one step further, several observations allow linking, to a certain extent, the degree of media coverage with the actual scrutiny behaviour of parliamentarians on these topics.

First, when looking at the content of parliamentary questions, the source of information triggering the scrutiny of parliamentarians can be identified on an occasional basis. Interestingly, several parliamentary actions refer directly to an article published in the media or on specialised publications produced by agricultural interest groups ${ }^{3}$ as their starting point. This importance of media coverage and of specialised publications as a source of information was also confirmed by several of our interviewees. Second, the subjects that have received more media attention (greening, direct payments, situation of young farmers and small farms, etc.) were also identified by the MPs in their scrutiny actions as the most salient issues of the CAP reform (greening, direct payments, etc.). This observation is also true for the LIFE programme. The media coverage mainly focused on concrete LIFE projects (such as the 'ELIA LIFE' project), as did some of the parliamentary questions formulated in the Walloon parliament. Finally, a strong link with civil society organisations is also spotted in the media coverage and in parliamentary activities. Most particularly, the Boerenbond and the Fédération wallonne de l'agriculture (FWA), the main agricultural interest groups, but also to a lesser extent interest groups representing young farmers ('Groene Kring' in Flanders and 'Fédération des Jeunes Agriculteurs' in Wallonia) and milk producers ('European Milk Board') are often cited as important sources of information. Most of these associations have also been auditioned in the preparatory work, leading to the adoption of the parliamentary resolutions of the CAP reform. Regarding the LIFE reform, the mobilisation of environmental organisations (such as Bond Beter Leefmilieu, Natuurpunt, Natagoria, etc.) at the domestic level was more limited, with only a few (critical) specialised publications.

The second explanatory factor we identified is the political salience of the CAP and LIFE negotiations, linked with the potential implementation influence of parliamentarians. Despite the fact that both EU negotiations lasted approximately two years, the CAP reform was debated much more (20 
times) at the ministerial level than the LIFE reform (four times). Of course, the agriculture and fisheries configuration of the Council meets on a more regular basis than the environment configuration, yet the CAP reform was discussed at almost all meetings at ministerial level during the negotiation. When looking more closely at 'A' and 'B' points of Council agendas, all discussions on the CAP except one (the adoption by the Council of the final act) were listed as ' $\mathrm{B}$ ' points, meaning that the issue needed particular attention. Regarding the LIFE negotiation, it was also debated in the Council as ' $\mathrm{B}$ ' points, but mostly under the title 'Any other business'. Finally, the way the negotiations of the CAP reform were presented in the media, and to a lesser extent in parliamentary actions, also pointed to the important differences between member states on the main CAP orientations (such as budget, direct payments and the greening of the CAP), depicting the CAP as a highly debated negotiation.

Yet, this needs to be discussed in relation to the potential implementing influence of (sub)national parliaments on these two reforms. Indeed, if a regional parliament does not have any impact on the implementation of the policy issue at the domestic level, the high salience of the topic at the EU level is not sufficient to trigger parliamentary scrutiny. Both with regard to political salience and to the implementation potential, there are significant differences between the CAP reform and the LIFE reform. Regarding the former, it is its perceived importance for the agricultural sector that triggered the attention of both parliaments. Most of the interviewees of both parliaments emphasised how crucial the European regulatory framework is for a policy domain such as agriculture (Interviews 7, 8, 9, 11; Interviews 1, 2, 3). Furthermore, except for the Libertarian LDD (a Flemish political party), MPs from all political groups (both Flemish and Walloon) widely participated in the debates on the CAP reform. During the legislative period 2009-14, the CAP reform was the most frequently discussed EU dossier in the Agricultural Committees of both parliaments and was considered to touch upon the key interests of the agricultural sector. Conversely, this situation is not observed in the case of the LIFE proposal. Interviews with members of the Environment Committee show that the LIFE reform passed under the radar of both Walloon and Flemish parliamentary committees dealing with environmental policies (Interview 12).

Also regarding parliament's role in the implementation process, there are significant differences between the CAP and the LIFE reforms. The main aim of the LIFE programme is to provide (co-)funding for environmental and climate action projects with a European added value in the member states. Once the legal framework and priorities are determined in the EU regulation, the margin of manoeuvre at national and regional levels is limited (Interview 13). On the other hand, the influence of subnational parliaments on the implementation of CAP is much greater. When analysing the content of the scrutiny instruments on the CAP reform, it is clear that most dealt with 
the implementation of the reform or on its consequences for the different aspects of Flemish and Walloon agriculture. The resolution adopted by the Walloon parliament is illustrative in this regard, with a specific section focusing on the implementation of the CAP in Wallonia and on the available margin of manoeuvre at the regional level. An important reason why the MPs focused specifically on the implementation of the CAP in their scrutiny is that their perceived impact on the EU negotiations was rather limited. Most interviewees acknowledged that they did not think that Belgium, and more specifically the subnational parliaments, could have a strong influence on the position of the Council of Ministers (Interviews 1, 3, 7, 8). In other words, parliamentarians focused on what they could influence: how the regional governments would use their margin for manoeuvre during the implementation stage of the CAP reform.

\section{Discussion}

Quite recently, scholars have increased the attention given to the potential of a multi-level parliamentary field (Crum \& Fossum, 2009). However, studies on the role of subnational parliaments in the EU decision-making process and more particularly on their behavioural adaptations are still lacking. We do agree with Borońska-Hryniewiecka (2013a) when she argues that 'if the input legitimacy of the EU is to be comprehensively evaluated, the analysis should also include the subnational dimension of the EU parliamentary field' (p. 1). Moreover, to capture fully the practice of Europe in regional parliaments, studies must also investigate activated control mechanisms and measure the EU-related activity in regional parliaments. Indeed, having strong oversight institutions does not mean that parliaments will use these opportunities to scrutinise effectively their executives.

In this article, we have analysed how and why the Flemish and Walloon parliaments have scrutinised the EU negotiations of the CAP and LIFE reforms during the term 2009-14. Nonetheless, such a research design inevitably suffers from limitations. First, our findings are very context-specific. The political-institutional situation of Belgium determines to some extent the scrutiny possibilities of the regional parliaments. The weak parliamentary position of both parliaments - as the lack of any binding instruments illustrates - does not prevent the MPs from engaging in scrutinising the executive, but it does have an impact on their focus: instead of constraining the executive, the MPs concentrate on gathering information. Second, we have compared the scrutiny of two similar reforms in two policy fields in which the Belgian regional level is pivotal. Consequently, the analysis with two case studies only does not allow for generalising our findings on a more aggregate level.

That being said, our data show that in policy fields that are regionalised, such as agricultural and environmental policies in Belgium, the EU takes an 
important place in the work of the regional legislative chambers. In addition, our case studies have provided insight into the motivational incentives for individual MPs to engage in scrutinising EU issues. The findings show that the level of mediatisation of an EU issue matters, among other reasons because articles in newspapers and specialised magazines provide an important source of information for the MPs to use in their scrutiny actions. The more attention that is dedicated to an issue - both in the media and through pressure groups - the more likely it is that MPs will trigger their parliamentary instruments. Furthermore, in their scrutiny behaviour the MPs focus on what they can actually influence: instead of trying to alter the negotiations on the EU-level, they concentrate on the implementation of the reform. Regarding the CAP, our results show that what matters for parliamentarians is to assess the potential impact of the reform for their agricultural sector and to enquire about the intentions of the government regarding its implementation. This finding goes in the direction of Bursens and Högenaueur's (2017, this issue) hypothesis, when they argue that the EU-related work of regional assemblies tends to focus on the regional dimension of $\mathrm{EU}$ policies, including questions on the implementation of European policies rather than on influencing EU legislative outcomes stricto sensu. It also explains why an issue with a low room for manoeuvre in the implementation phase, such as the LIFE reform, attracts less parliamentary attention.

\section{Notes}

1. We identified agricultural and environmental-related questions relying on the thematic categorisation provided by both parliaments. In the Walloon parliament, all parliamentary questions are labelled in themes and subthemes. Actions classified in the broader themes 'environment', and several sub-categories labelled under the themes 'water policy' and 'nature protection' were taken into consideration for environmental policies. For agriculture, we coded actions regrouped under the themes 'industrial sector: agriculture and sylviculture', 'rural developments' and 'rural world'. For the Flemish parliament, it is not possible to search directly on themes in the database; we applied a two-step approach. First, to keep our set as broad as possible, we used two general references: 'agriculture' and 'environment'. Second, we narrowed our search results to those parliamentary instruments that were labelled under the themes 'agriculture and fisheries' and 'nature and environment'. In a next step, we took all actions exclusively on fisheries out of the data set.

2. When looking at the agricultural policy field, respectively three MPs for the Walloon parliament and four MPs for the Flemish parliament are responsible for more than 50 per cent of EU scrutiny actions. This trend is also observable, but to a lesser extent, for environmental policies. Five MPs for the Walloon parliament and eight MPs for the Flemish parliament were needed to reach 50 per cent of EU actions.

3. In Flanders: 'Boeren en Tuinders' for the Boerenbond. In Wallonia: 'Plein Champs' for the FWA. 


\section{Disclosure statement}

No potential conflict of interest was reported by the authors.

\section{Notes on contributors}

François Randour is a researcher at the Institut de Sciences Politiques Louvain Europe (ISPOLE) of the Universite catholique de Louvain (Belgium). His research interests focus on federalism and on the role of the Austrian, Belgian and German (sub)national parliaments in the European Union. François Randour has published articles in the Journal of Common Market Studies, Revue des affaires européennes and in the International Review of Administrative Sciences. Email: francois.randour@ uclouvain.be

Wouter Wolfs is a researcher at the KU Leuven Public Governance Institute (Belgium). He is preparing a $\mathrm{PhD}$ in political science on the finance regime of Europarties and political groups in the European Parliament. Furthermore, his research focus is on the functioning of national parliaments in the European Union, the Europeanisation of political parties and Euroscepticism. Email: wouter.wolfs@soc. kuleuven.be

\section{References}

Abels, G., \& Eppler, A. (Eds.). (2016). Subnational parliaments in an EU multi-level parliamentary system: Taking stock of the post-Lisbon era. Innsbruck: Studienverlag.

Auel, K. (2007). Democratic accountability and national parliaments: Redefining the impact of parliamentary scrutiny in EU affairs. European Law Journal, 13(4), 487-504.

Auel, K., \& Christiansen, T. (2015). After Lisbon: National parliaments in the European Union. West European Politics, 38(2), 261-281.

Auel, K., Rozenberg, O., \& Tacea, A. (2015a). To scrutinise or not to scrutinise? Explaining variation in EU-related activities in national parliaments. West European Politics, 38(2), 282-304.

Auel, K., Rozenberg, O., \& Tacea, A. (2015b). Fighting back? And if so, how? Measuring parliamentary strenght and activity in EU affairs. In C. Hefftler, C. Neuhold, O. Rozenberg, \& J. Smith (Eds.), The palgrave handbook of national parliaments and the European Union (pp. 60-93). Basingstoke: Palgrave Macmillan.

Auel, K., Rozenberg, O., Thomas, A., \& Tacea, A. (2012). Lost in transaction, Parliamentary reserves in EU Bargains. (OPAL online Paper Series, 2012/10).

Beyers, J., \& Bursens, P. (2006). The european rescue of the federal state: How europeanisation shapes the Belgian state. West European Politics, 29(5), 1057-1078.

Beyers, J., Delreux, T., \& Steensels, C. (2004). The Europeanisation of intergovernmental cooperation and conflict resolution in Belgium: The case of agriculture. Perspectives on European Politics and Society, 5(1), 103-134.

Borońska-Hryniewiecka, K. (2013a). Regions and subsidiarity after Lisbon: Overcoming the 'Regional Blindness? UISS Guido Carli School of Government, SOG- WP3.

Borońska-Hryniewiecka, K. (2013b). Subnational parliaments in EU policy control: Explaining the variations across Europe. (European University Institute working papers, 38). 
Bursens, P., \& Högenaueur, A.-L. (2017, this issue). Regional parliaments in the EU multilevel parliamentary system. Journal of Legislative Studies. doi:10.1080/ 13572334.2017.1329984

Bursens, P., Maes, F., \& Vileyn, M. (2015). Belgian regional assemblies in EU policymaking: The more parliaments, the less participation in EU affairs. In G. Abels, \& A. Eppler (Eds.), Subnational parliaments in an EU multi-level parliamentary system: Taking stock of the post-Lisbon era (pp. 175-192). Innsbruck: Studienverlag.

Carmona Contreras, A. M. (2012). Hacia la europeización de los parlamentos autonómicos? Reflexiones al hilo del mecanismo de alerta temprana. Revista D'estudis Autonòmics i Federals, 16, 141-176.

Carter, C., \& McLeod, A. (2005). The scottish parliament and the European Union: Analysing regional parliamentary engagement. In S. Weatherill, \& U. Bernitz (Eds.), The role of regions and subnational actors in Europe (pp. 67-88). Oxford: Hart Publishing.

Crum, B., \& Fossum, J. (2009). The multilevel parliamentary field: A framework for theorizing representative democracy in the EU. European Political Science Review, 1(2), 249-271.

De Ruiter, R. (2013). Under the radar? National parliaments and the ordinary legislative procedure in the european union. Journal of European Public Policy, 20(8), 1196-1212.

De Wilde, P. (2008). Media coverage and national parliaments in EU Policy-formulation: Debates on the EU budget in the Netherlands 1992-2005. (Recon online working paper, 3).

De Winter, L., \& Wolfs, W. (2017). Policy analysis in the Belgian legislatures: The marginal role of a structurally weak parliament in a partitocracy with no scientific and political tradition of policy analysis. In M. Brans, \& D. Aubin (Eds.), Policy analysis in Belgium (pp. 129-150). Bristol: Policy Press.

Delreux, T., \& Randour, F. (2015). Belgium: Institutional and administrative adaptation but limited political interest. In C. Hefftler, C. Neuhold, O. Rozenberg, \& J. Smith (Eds.), The palgrave handbook of national parliaments and the European Union (pp. 153-169). Basingstoke: Palgrave Macmillan.

Depauw, S. (2003). Government party discipline in parliamentary democracies: The cases of Belgium, France and the United Kingdom in the 1990s. Journal of Legislative Studies, 9(4), 130-146.

Diplomatie Belgium. (2016). Coordination de la politique européenne et de représentation de la Belgique. Retreived from http://diplomatie.belgium.be/fr/ politique/coordination_affaires_europeennes/DGE/coordination

Finke, D., \& Dannwolf, T. (2013). Domestic scrutiny of European Union Politics: Between whistle blowing and opposition control. European Journal of Political Research, 52(6), 715-746.

Gattermann, K., \& Hefftler, C. (2015). Beyond institutional capacity: Political motivation and parliamentary behaviour in the early warning system. West European Politics, 38(2), 305-334.

Goetz, K. H., \& Meyer-Sahling, J.-H. (2008). The Europeanisation of national political systems: Parliaments and executives. Living Reviews in European Governance, 3(2). Retrieved from http://www.europeangovernance-livingreviews.org/Articles/lreg2008-2/

Martin, S. (2011). Parliamentary questions, the behaviour of legislators, and the function of legislatures: An introduction. The Journal of Legislative Studies, 17(3), 259270. 
Nugent, N. (2006). The government and politics of the European Union. The European Union Series. Bakingstoke: Palgrave Macmillan.

Putnam, R. (1988). Diplomacy and Domestic Politics: the logic of Two-level games. International Organization 42(3), 427-460.

Rozenberg, O., \& Martin, S. (2011). Questioning parliamentary questions. The Journal of Legislative Studies, 17(3), 394-404.

Saalfeld, T. (2005). Deliberate delegation or abdication? Government backbenchers, ministers and european union legislation. The Journal of Legislative Studies, 11 (3-4), 343-371.

Schmitt, P., Ruys, T., \& Marx, A. (2013). The subsidiarity early warning system of the Lisbon Treaty - the role of regional parliaments with legislative powers and other subnational authorities. Report written by the Leuven Center for Global for the Committee of the Regions.

Schneider, E., Rittberger, B., \& Wonka, A. (2014). Adapting to Europe? Regional MP's involvement in EU affairs in Germany. Regional and Federal Studies, 24(4), 407427.

Vara Arribas, G., \& Bourdin, D. (2011). Le rôle des parlements régionaux dans l'évaluation de la subsidiarité dans le cadre du mécanisme d'alerte précoce $\mathrm{du}$ traité de Lisbonne. Report prepared for the Comité des Régions.

Warntjen, A. (2012). Measuring salience in EU legislative politics. European Union Politics, 13(1), 168-182.

Winzen, T. (2013). European integration and national parliamentary oversight institutions. European Union Politics, 14(2), 297-323.

\section{Interviews}

Interview 1: A Walloon parliamentarian, Majority, Namur, October 2014.

Interview 2: A Walloon parliamentarian, Majority, Namur, October 2014.

Interview 3: A Walloon parliamentarian, Opposition, Namur, November 2014.

Interview 4: Clerk of the Walloon parliament, Namur, November 2014.

Interview 5: An official from the Belgian Permanent Representation, Brussels, December 2014.

Interview 6: A Flemish parliamentarian, Majority, Brussels, November 2014.

Interview 7: Clerk of the Flemish parliament, Brussels, November 2014.

Interview 8: A Flemish parliamentarian, Opposition, phone interview, July 2015.

Interview 9: A Flemish parliamentarian, Majority, Leuven, August 2015.

Interview 10: A Flemish Parliamentarian, Opposition, phone interview, September 2015.

Interview 11: A Flemish Parliamentarian, Opposition, Brussels, January 2016.

Interview 12: A Walloon Parliamentarian, Majority, Namur, April 2016.

Interview 13: An official from a regional ministry (environment), phone interview, October 2016. 